Journal Universitas Muhammadiyah Gresik Engineering, Social Science, and Health International Conference (UMGESHIC)

UMGCINMATIC : $1^{\text {st }}$ Rethinking Education during Covid-19 Era: Challange and Innovation

\title{
THE INFLUENCE OF INDIVIDUAL CHARACTERISTICS ON EMPLOYEE ENGAGEMENT: LEADERSHIP STYLE AS AN INTERVENING VARIABLE
}

\author{
Author \\ Ade Septiarisna Warindra ${ }^{1}$, Djoko Soelistya $^{2}$, Eva Desembrianita ${ }^{3}$ \\ Universitas Muhammadiyah Gresik ${ }^{1}$, Universitas Muhammadiyah Gresik ${ }^{2}$, Universitas \\ Muhammadiyah Gresik ${ }^{3}$ \\ djoko_soelistya@umg.ac.id ${ }^{1}$
}

\begin{abstract}
In the business world in the modern era of industry 4.0, business development is very tight in its competition, where the company always has the goal of obtaining business profits and trying to maintain and develop the viability of the business itself, especially the individual characteristics of employees are indispensable in encouraging company goals and in Manufacturing Companies. Plastic Woven Packaging in Gresik, has a problem with the performance of its employees which is less than optimal and tends to decline so it needs to be evaluated and found a solution so that the company's goals can be achieved.

This study aims to analyze the influence of individual characteristics possessed by employees on their performance in the company through the leadership style that exists in the company while in this study using quantitative methods with a population of employees of the Plastic Woven Packaging Manufacturing Company in Gresik using a sample of the production department of 100 respondents, through SmartPLS 3.0 analysis method

The results of this study indicate that the influence of (1) Individual Characteristics has a significant direct effect on Performance, (2) Individual Characteristics has a significant direct effect on Leadership Style and (3) Leadership Style has a significant direct effect on Performance, while for the results of indirect influence through mediating variable Leadership Style that (4) Individual Characteristics have a significant direct effect and can improve employee performance although not through leadership style as a mediating variable, therefore companies need to pay attention to the behavior of individual characteristics of their employees especially to improve their performance and companies also need to pay attention to other variables that can affect employee performance.
\end{abstract}

Keywords: Individual Characteristics, Leadership Style, Employee Performance 


\section{INTRODUCTION}

Business competition is getting more competitive day by day, the emergence of new companies of the same type by using a strategy of offering a much lower selling price is a threat to companies that have already operated. Therefore, the company needs to make continuous improvements that can provide an increase in the quality of resources by developing and regenerating. Preparing new professional human resources with quality individual characteristics, ready to create and provide added value for the company.

(Wirawan and Afani, 2018) convey one of several factors that support a success, the existence of a development or the absence of a development of a company when making efforts to achieve the desired goals, it takes an effort from the HR owned by the company, because the problem itself is in the field of resources Human beings are one of several important aspects or supports for a company organization and are also conveyed by (Mangkunegara and Agustine, 2016) that HR is very important and valuable to control and manage in order to achieve company goals.

The Plastic Woven Packaging Manufacturing Company in Gresik, has a problem with a decrease in the performance of its employees, and it can be seen in its productivity results, which have decreased in the last 3 years, from 2018 to 2020 and can be seen in graph 1 below:

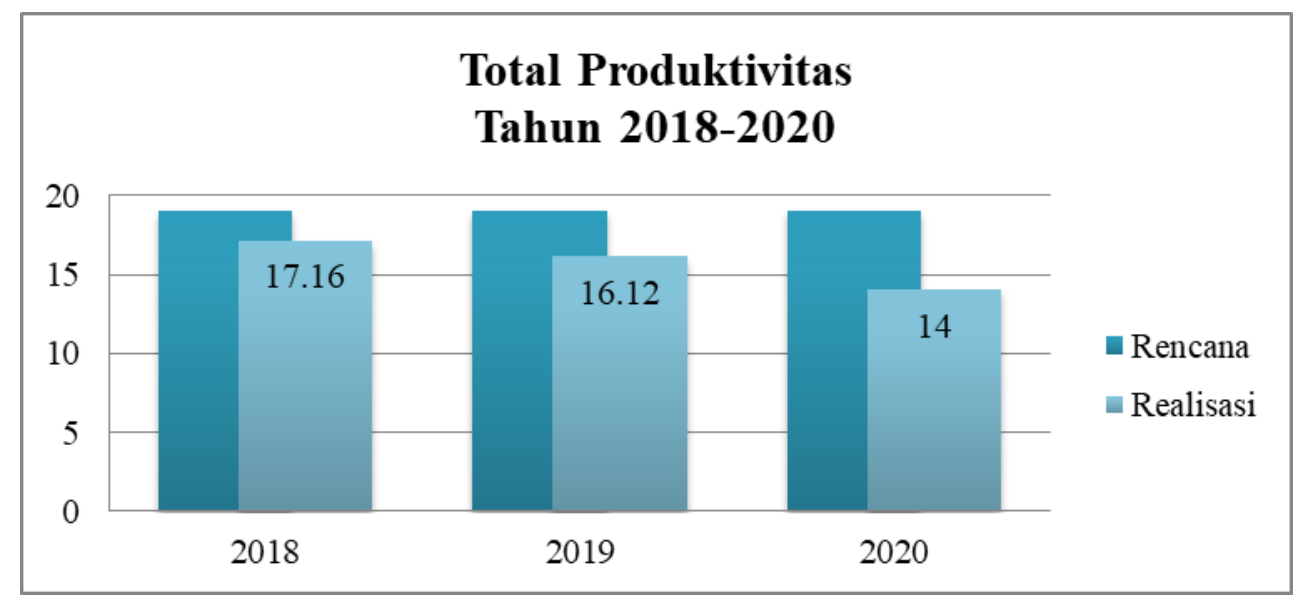

Graph 1. Total Productivity

From the results of the data above, it seems that it is still far from what is expected, so this condition is thought to affect employee performance. From observations and interviews with management that there is indeed a decrease in employee performance results, it is suspected that there are individual characteristics of employees that affect performance.

Humans as an important component element, because as planners and determinants of the realization of the system that is run, but having employees with individual characteristics is not easy. Within the company, there are employees with different individual characteristics. Individual characteristics are characteristics that distinguish one another about initiative, motivation, problem solving, the ability to survive to stay strong at work until it is completed, and the ability to adapt to changes in the work environment that indirectly have an impact on performance.(Suryani, Sugianingrat and Laksemini, 2020);(Pramundi and , Mochamad Mochklas, 2021) 
Violation of Department Production is increasing every year, it can be concluded that the lack of bad individual characteristics causes the high number of violations committed by employees coupled with the leadership applied to employees. department This is not relevant to the characteristics of the employees they lead.

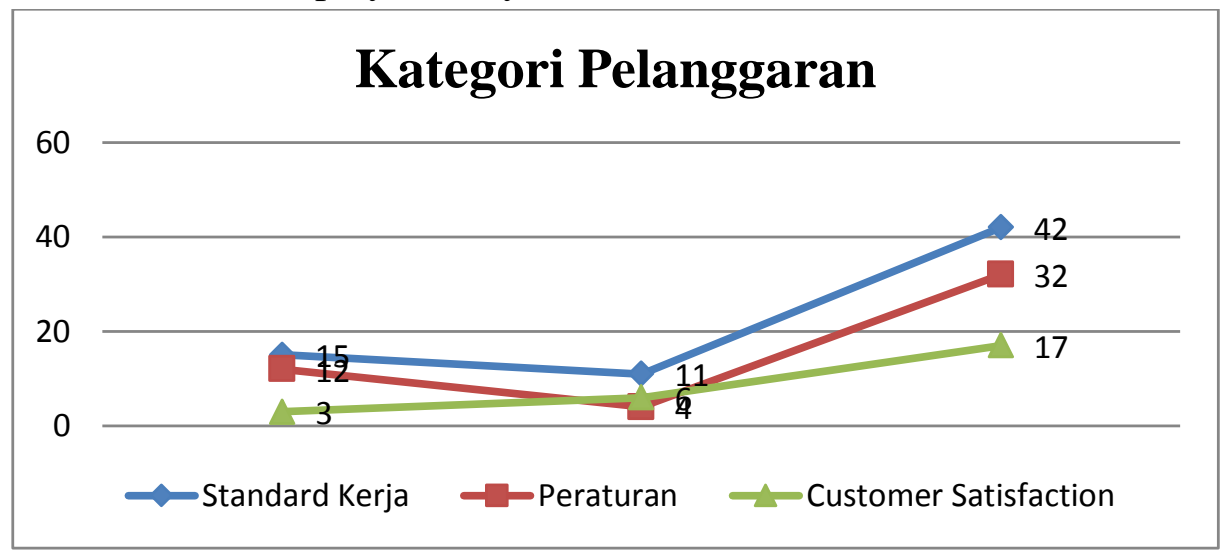

\section{Graph 2. Violation Category \\ Department Production}

Source: Data Human Resources Department

In graph 2. describes the Categories of Types of Violations committed by Employees DepartmentProduction. Violations are divided into 2, namely Internal Violations and External Violations. Offense CategoryStandardWork and Rule Violations are classified as Internal Violations, while Customer Satisfaction Violations are classified as External Violations, because this Type of Violation has involved other parties outside the Company. Types of External Violations are types of serious violations, because they directly affect the level of customer satisfaction and decrease the credibility and profits obtained by the company because it causes customers not to repeat orders or lose customers.

Meanwhile, the decrease in employee performance is also suspected to have an effect on presenceemployees to the company, as shown in table 1, which shows that the total work absenteeism of employees increased to $33 \%$ and continued in 2020 by $42 \%$. This shows that the higher the percentage of employee absenteeism, the lower the productivity level that can be obtained.

\begin{tabular}{|l|l|l|l|}
\hline Attendance Criteria & $\mathbf{2 0 1}$ & $\mathbf{2 0 1 9}$ & $\mathbf{2 0 2 0}$ \\
\hline Sick & 35 & 39 & 50 \\
\hline Permission & 6 & 18 & 23 \\
\hline Paid leave & 14 & 21 & 31 \\
\hline Alpha & 17 & 20 & 21 \\
\hline Number of Days Absent & 72 & 98 & 125 \\
\hline Number of working days & 297 & 300 & 299 \\
\hline Percentage & $\mathbf{2 4}$ & $\mathbf{3 3 \%}$ & $\mathbf{4 2 \%}$ \\
& $\mathbf{\%}$ & & \\
\hline
\end{tabular}




\section{Table 1. Employee Attendance}

Source: Data Human Resource Department

(Islami and Kusumaningsih, 2020) in the results of his research proves that "There is a significant negative relationship between the perception of an autocratic leadership style and employee performance. Implementation of more leadership activities towards suppressing employees may cause an employee to achieve job satisfaction, but it may not necessarily have a positive influence on the personality formation of subordinates to sincerely work towards achieving organization goals. This shows that there is an influence between leadership style on job satisfaction."

The gaps that occur in Gresik manufacturing companies are found and illustrated in the following table:

\begin{tabular}{|c|c|c|}
\hline gap & Researcher & Finding \\
\hline \multicolumn{3}{|c|}{ Issue: Individual Characteristics of Employee Performance } \\
\hline $\begin{array}{l}\text { Employee Performance } \\
\text { is Influenced by } \\
\text { Individual } \\
\text { Characteristics }\end{array}$ & $\begin{array}{l}\text { (Suhepi and Shah, } \\
\text { 2018), (Gaffar, 2017), } \\
\text { (Faiqoh, HS and } \\
\text { Taufiq, 2020) }\end{array}$ & $\begin{array}{l}\text { The higher the } \\
\text { Individual } \\
\text { Characteristics variable, } \\
\text { the better employee } \\
\text { performance }\end{array}$ \\
\hline $\begin{array}{l}\text { Employee Performance } \\
\text { is not influenced by } \\
\text { Individual } \\
\text { Characteristics }\end{array}$ & $\begin{array}{l}\text { (Kridharta and } \\
\text { Rusdianti, 2017) }\end{array}$ & $\begin{array}{l}\text { The higher the } \\
\text { Individual } \\
\text { Characteristics variable, } \\
\text { the higher the employee } \\
\text { performance or there is } \\
\text { no effect }\end{array}$ \\
\hline
\end{tabular}

Table 2. Research Gap Findings

\section{METHODS}

The following research uses a quantitative approach (Sugiyono, 2013), provides a definition of quantitative methods, namely research data in the form of numbers and analyzes data using statistical procedures, while the purpose of the following research is causality research which has the aim of examining the relationship between the variables to be studied, as stated (Iqbal, 2015) 


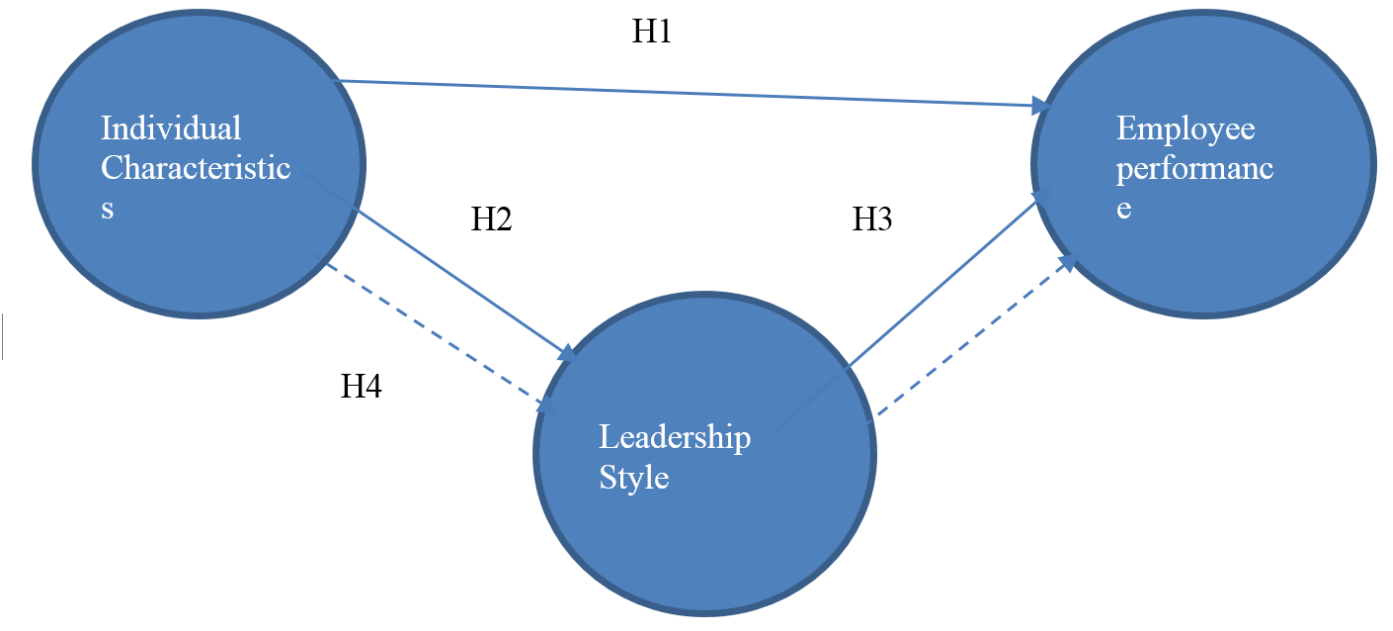

Figure 1 conceptual framework

The hypotheses created in the following research are:

1. H1: there is a direct effect of individual characteristics on employee performance

2. $\mathrm{H} 2$ : there is a direct effect of individual characteristics on leadership style

3. H3: there is a direct effect of leadership style on performance

4. $\mathrm{H} 4$ : there is an indirect effect of individual characteristics on employee performance through leadership style as an intervening variable

Population by (Sugiyono, 2013) "is a generalization area consisting of objector subjects that have certain qualities and characteristics that have been determined by the researcher to be studied and then draw conclusions. In other words, the total number ofobject. The population of this study are employees of manufacturing companies in GresikDepartment Production of 945 people. And the method for determining the number of samples uses the formula from Slovin for 100 employees with an error tolerance of $10 \%$

\section{RESULT AND DISCUSSION}

In the following research, hypothesis testing uses analytical techniques using the Smart Partial Least Square (PLS) 3.0 program, and can be seen in the schematic model of the PLS 3.0 program tested in Figure 2:

Individual Characteristic

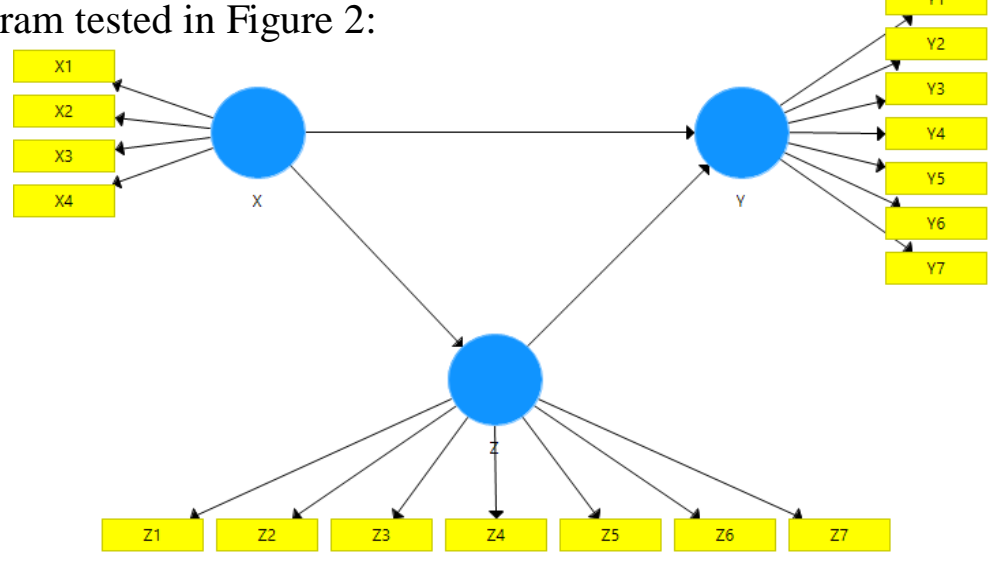

Figure 2

Smart Partial Least Square (PLS) Model Schematic

a. Evaluation of Measurement (Outer) Model

Based on the results of the analysis "Partial Least Square (PLS) with PLS Argorithm 
for validity and reliability testing, model determination coefficient and path coefficient for equation model, the following is the image generated based on the output results of the PLS Argorithm SmartPLS, can be seen in the figure 3,

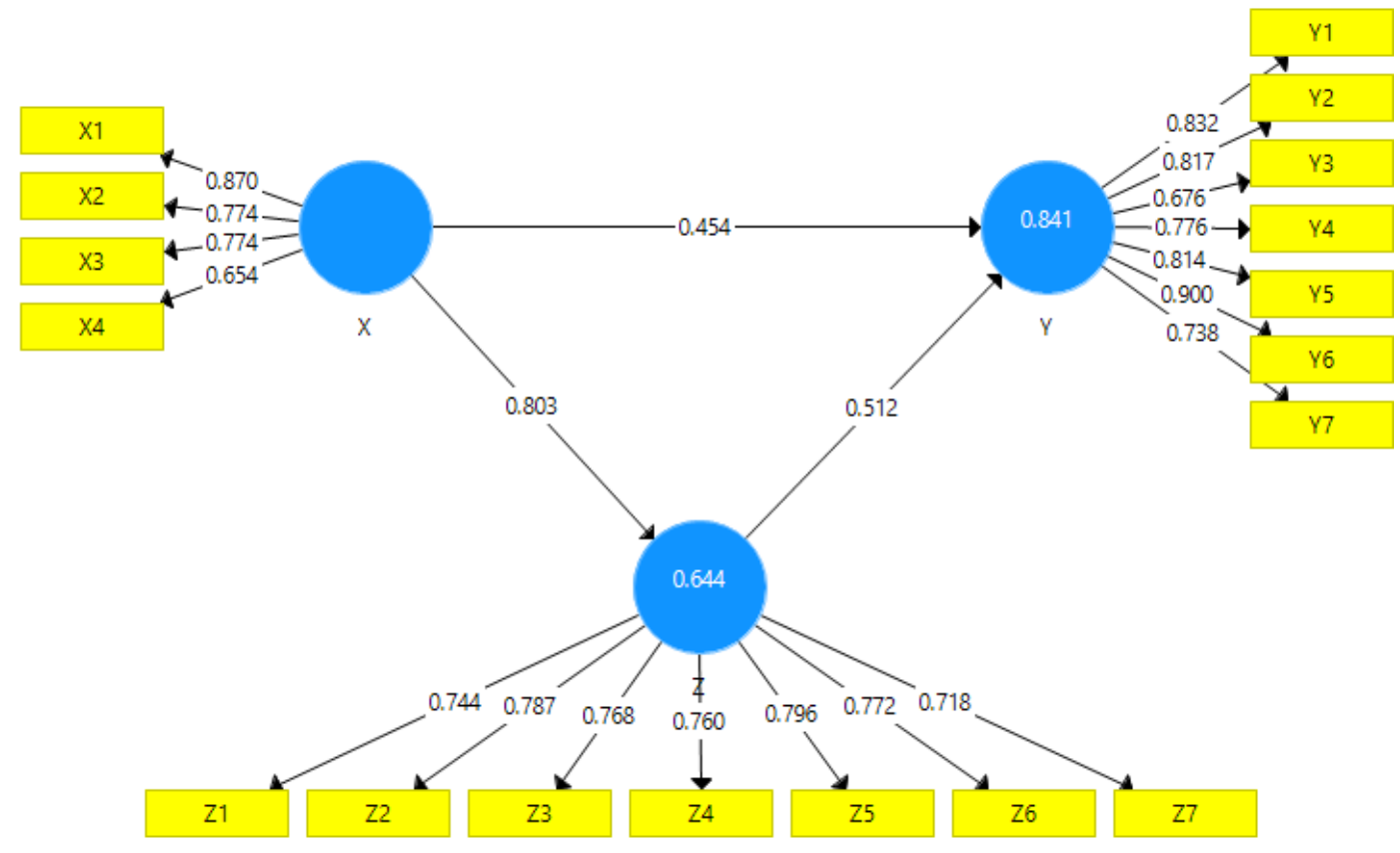

Figure 3

Evaluation of Measurement (Outer) Model

b. Convergent Validity

Convergent validity from the measurement model with reflective indicators, it can be seen from the correlation between item scores/indicators and their construct scores. Reflective Sizeindividualis said to be high if it has a correlation of more than 0.70 with the construct to be measured. However, at the research stage of the scale development stage, a loading of 0.50 to 0.60 is still acceptable(Latan and Ghozali, 2016). The following is the value of the outer loading of each indicator on the research variable:

\begin{tabular}{lcccc}
\multicolumn{1}{c}{ Variable } & \multicolumn{1}{c}{ Indicator } & $\mathbf{X}$ & $\mathbf{Z}$ & $\mathbf{Y}$ \\
\hline Individual & X1 & 0.870 & \\
Characteristics & X2 & 0.774 & \\
& X3 & 0.774 & \\
Leadership Style & X4 & 0.654 & \\
& Z1 & & 0.744 \\
& Z2 & & 0.787 \\
& Z3 & & 0.768 \\
& Z4 & 0.760 \\
& Z5 & 0.796 \\
& Z6 & 0.772
\end{tabular}




$\begin{array}{lll} & \text { Z7 } & 0.718 \\ \text { Employee } & \text { Y1 } & \\ \text { performance } & \text { Y2 } & 0.832 \\ & \text { Y3 } & 0.817 \\ \text { Y4 } & 0.676 \\ \text { Y5 } & 0.776 \\ \text { Y6 } & 0.814 \\ \text { Y7 } & 0.900 \\ & & 0.738\end{array}$

Table 3. Outer Loading Convergent Validity

Based on "the data in table 3. above, it is known that each indicator of the research variable has a value of outer loading $>0.7$. However, it appears that there are still some indicators that have an outer loading value of < 0.7.(Latan and Ghozali, 2016), the outer loading value between $0.5-0.6$ is considered sufficient to meet the convergent validity requirements.

c. Discriminant Validity

Discriminant validity is the value of the cross loading factor that is useful for knowing whether the construct has an adequate discriminant, namely by comparing the loading value on the intended construct that must be greater than the other values. Withstandardthe value for each construct must be greater than 0.7 . based on table 4.12 the value of cross loading on each construct has a value of more than 0.7. this shows that the manifest variable in this study has correctly explained the latent variable and proved that all of the items were valid. The following is the cross loading value of each indicator:

\begin{tabular}{ccccc} 
Item Code & $\mathbf{X}$ & $\mathbf{Z}$ & $\mathbf{Y}$ \\
\hline $\mathbf{X 1}$ & 0.870 & 0.632 & 0.732 \\
$\mathbf{X 2}$ & 0.774 & 0.674 & 0.678 \\
$\mathbf{X 3}$ & 0.774 & 0.575 & 0.686 \\
$\mathbf{X 4}$ & 0.654 & 0.593 & 0.562 \\
$\mathbf{Z 1}$ & 0.673 & 0.744 & 0.716 \\
$\mathbf{Z 2}$ & 0.603 & 0.787 & 0.684 \\
$\mathbf{Z 3}$ & 0.623 & 0.768 & 0.653 \\
$\mathbf{Z 4}$ & 0.621 & 0.760 & 0.659 \\
$\mathbf{Z 5}$ & 0.596 & 0.796 & 0.675 \\
$\mathbf{Z 6}$ & 0.608 & 0.772 & 0.652 \\
$\mathbf{Z 7}$ & 0.557 & 0.718 & 0.639 \\
$\mathbf{Y 1}$ & 0.720 & 0.734 & 0.832 \\
$\mathbf{Y 2}$ & 0.719 & 0.722 & 0.817
\end{tabular}




\begin{tabular}{lll|l} 
Y3 & 0.600 & 0.537 & 0.676 \\
Y4 & 0.633 & 0.697 & 0.776 \\
Y5 & 0.667 & 0.706 & 0.814 \\
Y6 & 0.850 & 0.832 & 0.900 \\
Y7 & 0.591 & 0.614 & 0.738
\end{tabular}

Table 4. Cross Loading Value

Based on the data presented in table 4. above, it can be seen that each indicator in the research variable has the largest cross loading value on the variable it forms compared to the cross loading value on other variables. Based on the results obtained, it can be stated that the indicators used in this study have good discriminant validity in compiling their respective variables.

In addition to observing the cross loading value, discriminant validity can also be known through other methods, namely by looking at the average variant extracted (AVE) value. (Fornell and Larcker, 1981). In(Latan and Ghozali, 2016)describes another test to assess the validity of the construct by looking at the AVE value. The model is said to be good if the AVE of each construct is greater than 0.50.

\begin{tabular}{|l|c|}
\multicolumn{1}{|c|}{ Variable } & Value of Average Variant Extracted \\
\hline Individual & 0.596 \\
Characteristics & \\
\hline Leadership Style & 0.584 \\
\hline Employee performance & 0.634 \\
\hline
\end{tabular}

Table 5. Average Variant Extracted (AVE) Value

Based on the data presented in table 5. above, it can be seen that each research variable has an Average Variant Extracted (AVE) value greater than 0.5. Thus, it can be stated that each variable has good discriminant validity.

d. Composite Reliability

Composite Reliabilitycis the part that is used to test the value of the reliability of the indicators on a variable. A variable can be declared to meet composite reliability if it has a composite reliability value $>0.6$. The following is the composite reliability value of each variable used in this study:

\begin{tabular}{|l|c|}
\multicolumn{1}{|c|}{ Variable } & Composite Reliability Value \\
\hline Individual Characteristics & 0.854 \\
\hline Leadership Style & 0.907 \\
\hline Employee performance & 0.923 \\
\hline
\end{tabular}

Table 6. Composite Reliability

Based on the data presented in table 6. above, it can be seen that the composite reliability value of all research variables is $>0.7$. The construct is declared reliable if the composite reliability and Cronbach alpha values are above 0.70(Latan and Ghozali, 2016). These results indicate that each variable has met composite reliability so that it can be concluded that all variables have a high level of reliability.

e. Cronbach Alpha 
Test reliability with composite reliabilityabove can be strengthened by using the value of cronbach alpha. A variable can be declared reliable or fulfills cronbach alpha if it has a cronbach alpha value $>0.7$. The following is the cronbach alpha value of each variable

\begin{tabular}{lc}
\multicolumn{1}{c}{ Variable } & Cronbach's Alpha . value \\
\hline Individual & 0.769 \\
Characteristics & \\
\hline Leadership Style & 0.881 \\
\hline Employee performance & 0.902 \\
\hline
\end{tabular}

Table 7. Cronbach's Alpha

Based on the data presented above in table 7. it can be seen that the Cronbach alpha value of each research variable is $>0.7$. The construct is declared reliable if the composite reliability and Cronbach alpha values are above 0.70(Latan and Ghozali, 2016). Thus these results can indicate that each research variable has met the requirements of the Cronbach alpha value, so it can be concluded that all variables have a high level of reliability.

f. Structural Model Test or Inner Model

Evaluation path coefficient used to show how strong the effect or influence of the independent variable ondependent variable. While the coefficient determination (RSquare) is used to measure how much the endogenous variable is influenced by other variables.(Marcoulides, Chin and Saunders, 2009)states that the results of R2 of 0.83 and above for endogenous latent variables in the structural model indicate the effect of exogenous variables (which affect) on endogenous variables (which are affected) is included in the good category. Meanwhile, if the result is $0.33-0.67$ then it is included in the medium category, and if the result is $0.19-0.33$ then it is included in the weak category.

\begin{tabular}{|c|c|c|}
\hline Construct & $\begin{array}{c}\text { Path } \\
\text { Coefficient }\end{array}$ & Information \\
\hline Leadership Style -> Employee Performance & 0.512 & Medium \\
\hline Individual Characteristics -> Leadership Style & 0.803 & Medium \\
\hline $\begin{array}{l}\text { Individual Characteristics } \quad->\quad \text { Employee } \\
\text { Performance }\end{array}$ & 0.454 & Medium \\
\hline
\end{tabular}

Table 8. Path Coefficient

Based on the inner model scheme that has been shown in table 8 . above, it can be explained that the largest path coefficient value is indicated by the influence of Individual Characteristics on Leadership Style, which is 0.803 . Then the second biggest influence is the influence of Leadership Style on Employee Performance of 0.512 . Based on the description of these results, it shows that all variables in this model have a path coefficient with a positive number. This shows that the greater the path coefficient value on one independent variable on the dependent variable, the stronger the influence between the independent variables on the dependent variable. 
g. Model Goodness Test (Goodness of Fit)

Based on data processing that has been carried out using the program smartPLS 3.0, the R-Square value is obtained as follows:

\begin{tabular}{|l|c|c|}
\hline \multicolumn{1}{|c}{ Variable } & R-Square . Value & R-Square Adjusted \\
\hline Leadership Style & 0.644 & 0.640 \\
\hline Employee performance & 0.841 & 0.838 \\
\hline
\end{tabular}

Table 9. R-Square . Value

Based on "the data in table 9. above, it can be seen that the R-Square value for the Leadership Style variable is 0.644 . Obtaining this value explains that the percentage of individual characteristics can be explained by the leadership style of $64.4 \%$. Then for the R-Square value obtained by the Employee Performance variable of 0.841. The value explains" that Individual Characteristics and Leadership Styles can be explained by Employee Performance by $84.1 \%$.

The goodness of fit assessment is known from the Q-Square value. The Q-Square value has the same meaning as the coefficient determination (R-Square) in regression analysis, where the higher the Q-Square, the model can be said to be better or more fit with the data. The results of the calculation of the value of Q-Square are as follows:":

$$
\begin{aligned}
\text { Q-Square } & =1-[(1-\mathrm{R} 21) \times(1-\mathrm{R} 22)] \\
& =1-[(1-0.644) \times(1-0.841)] \\
& =1-(0.356 \times 0.159) \\
& =1-0.056 \\
& =0.944
\end{aligned}
$$

Based on the calculation results above, the Q-Square value is 0.944. This shows the magnitude of the diversity of the research data that can be explained by the research model is $94.4 \%$. While the remaining $5.6 \%$ is explained by other factors that are outside the research model. Thus, from these results, this research model can be declared to have a good and positive goodness of fit.

h. Live Effect Test

The next test is to see the significance of the effect between variable by looking at the value of the parameter coefficients and the value of the statistical significance of $\mathrm{T}$, namely through the bootstrapping method (Latan and Ghozali, 2016). In testing the hypothesis, it can be seen from the t-statistical value and probability value. For hypothesis testing, namely by using statistical values, for alpha $5 \%$ the t-statistic value

\begin{tabular}{|c|c|c|c|c|c|}
\hline Нро & Variable & & $\begin{array}{r}\text { Original } \\
\text { Sample }\end{array}$ & $\begin{array}{l}\text { T Statistics } \\
(|\mathrm{O} / \mathrm{STDEV}|)\end{array}$ & P Values \\
\hline 1 & $\begin{array}{l}\text { Individual Characteristics } \\
\text { Employee Performance }\end{array}$ & $\rightarrow$ & 0.865 & 25,779 & 0.000 \\
\hline
\end{tabular}
used is 1.96. So the acceptance/rejection criteriahypothesis is $\mathrm{Ha}$ accepted and H0 rejectedwhen t-statistic $>1.96$. To reject/accept the hypothesis using probability then Haacceptedif the $\mathrm{p}$ value $<0.05$. The following are the results of hypothesis testing obtained in this study through the inner model: 
UMGCINMATIC : $1^{\text {st }}$ Rethinking Education during Covid-19 Era: Challange and Innovation Volume 1 No 2

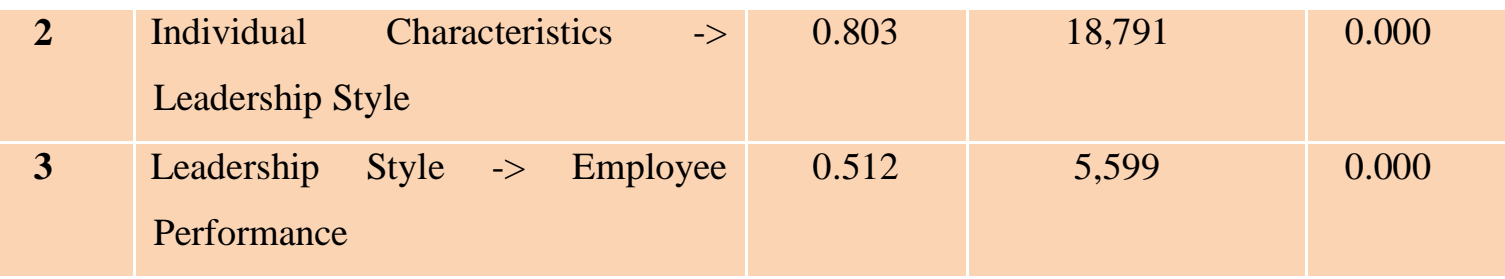

Table 10. T-Statistics and P-Values

Hypothesis of Effect of T-Statistics P-Values Results Based on the data presented in table 10 above, it can be seen that of the 5 hypotheses proposed in this study, all of them can be accepted because each of the effects shown has a P-Values value $<0.05$.

So that it can be stated that the independent variable to the dependent has a significant influence. The following is a breakdown of the influence between variables:

1) The Influence of Individual Characteristics (X) on Employee Performance ( $Y$ )

Based on the table above, it can be seen that for testing the Individual Characteristics $(\mathrm{X})$ variable on employee performance, the $\mathrm{T}$ statistics value is 25,779 with an -value of 0.000 . Because the value of -value is smaller than $(0.000$ $<0.05$ ), then H0 is rejected, thus there is a significant effect of Individual Characteristics (X) on Employee Performance (Y).

2) Influence of Individual Characteristics (X) on Leadership Style (Z)

Based on the table above, it can be seen that for testing the Individual Characteristics (X) variable on Leadership Style, the T statistics value is 18,791 with an -value of 0.000 . Because the -value is smaller than $(0.000<0.05)$, then $\mathrm{H} 0$ is rejected, thus there is a significant effect of Individual Characteristics (X) on Leadership Style (Z).

3) The Influence of Leadership Style (Z) on Employee Performance (Y)

Based on the table above, it can be seen that for testing the Leadership Style (Z) variable on Employee Performance (Y), the T statistics value is 5.599 with an value of 0.000 . Because the value of -value is smaller than $(0.000<0.05)$, then $\mathrm{H} 0$ is rejected, thus there is a significant effect of Leadership Style ( $\mathrm{Z}$ ) on Employee Performance (Y).

i. Indirect Effect Test

Testing the indirect effect hypothesis was carried out using the resampling bootstrapping technique method. Alternative approach to test the significance of mediation(Bollen and Stine, 1990). PLS-SEM Mediation Effects in(Latan and Ghozali, 2016) Based on a theoretical point of view, generally the application of mediation is to explain why there is a relationship between exogenous and endogenous constructs." before looking at the mediating effect on the mediator variable, it must first be seen whether there is a significant effect on the dependent variable. Therefore, according to Hair et al. in(Latan and Ghozali, 2016) top test "The effect of the mediator variable was carried out after bootstrapping to first see the significance of the effect. If there is no significant effect, then no further test of the mediation effect is carried out. Furthermore, hypotheses 6 and 7 predict the mediation effect using Baron and Kenny's analysis which suggests that a mediation relationship occurs when:

1) The independent variable has a significant effect on the dependent variable.

2) The independent variable has a significant effect on the mediator variable.

3) The mediator variable has a significant effect on the dependent variable. 
4) Full mediation (full/perfect mediation) "occurs if the effect of the independent variable on the dependent variable directly is significant, but the effect becomes insignificant when it involves the mediating variable. Partial mediation occurs if the influence of the independent variable on the dependent variable, either directly or indirectly, is significant. However, the regression coefficient of the independent influence on the dependent decreases when the mediating variable is included."

The following are the results of data processing to determine the independent variables "on the dependent variable, the independent variable on the mediator variable, the mediator variable affects the dependent variable" :

\begin{tabular}{|l|c|c|}
\multicolumn{1}{|c|}{ Variable } & $\begin{array}{c}\text { T Statistics } \\
\text { (|O/STDEV|) }\end{array}$ & P Values \\
\hline Individual Characteristics -> Leadership Style & 18,791 & 0.000 \\
\hline Leadership Style -> Employee Performance & 5,599 & 0.000 \\
\hline
\end{tabular}

Table 11. T-Statistics and P-Values

Based on the table above, it can be seen that the independent variable has a significant effect on the dependent variable, the independent variable has a significant effect on the mediator variable, and the mediator variable has a significant effect on the dependent variable. So based on these results, it can be concluded that the leadership style mediating variable is a full mediation variable (perfect mediation). Full mediation (full/perfect mediation) occurs if the effect of the independent variable on the dependent variable directly is significant, but the effect becomes insignificant when it involves the mediating variable. Based on these results, the indirect effect hypothesis will be tested:

\begin{tabular}{|c|c|c|c|c|}
\hline Нро & Variable & $\begin{array}{c}\text { Original } \\
\text { Sample }\end{array}$ & $\begin{array}{c}\text { T Statistics } \\
(|\mathrm{O} / \mathrm{STDEV}|)\end{array}$ & P Values \\
\hline 5 & $\begin{array}{l}\text { Individual Characteristics } \rightarrow \\
\text { Leadership Style } \rightarrow \text { Employee } \\
\text { Performance }\end{array}$ & 0.411 & 5,668 & 0.000 \\
\hline
\end{tabular}

Table 12. T-Statistics and P-Values

Based on the calculation of the path coefficient, it appears that:

Total Influence of Individual Characteristics (X) on Employee Performance (Y) through Leadership Style (Z) obtained T-statistics of 5.668 with -value of 0.000 . Because the value is smaller than $(0.000<0.05)$, then $\mathrm{H} 0$ is rejected, thus there is a significant effect of Individual Characteristics (X) on Employee Performance (Y) through" Leadership Style (Z)

\section{CONCLUSIONS AND SUGGESTIONS}

a. Individual Characteristics Affect Employee Performance

The results showed that testing the Individual Characteristics $(X)$ variable on employee performance obtained a $\mathrm{T}$ statistic value of 25,779 with an -value of 0.000 . Because the -value is smaller than $(0.000<0.05), \mathrm{H} 0$ is therefore rejected. There is a significant effect of Individual Characteristics (X) on Employee Performance (Y).

Conditions related to Individual Characteristics that exist in Gresik manufacturing company employees are not good, this can be reflected in irresponsible behavior or 
often assigning blame to others. department others related to the problems that occurred in his department, resulting in misunderstanding and acceptance, unsportsmanlike behavior, and employee behavior that is reluctant to help different coworkers department. So based on the results of the study if the individual characteristics are fostered and raised, employee performance will increase.

The results of this study support the results of previous research by (Primadani and Sumiati, 2019) with the research title "The Influence of Individual Characteristics, Employee Development and Employee Commitment to Job Satisfaction and Employee Performance at PT. Saraya Anugrah Sidoarjo" with the results of the study that the Individual Characteristics variable has a significant effect on employee performance.

b. Individual Characteristics Affect Leadership Style Variable testing can be seen for testing the Individual Characteristics (X) variable on Leadership Style, the T statistics value is 18,791 with an -value of 0.000. Because the -value is smaller than $(0.000<0.05)$, then $\mathrm{H} 0$ is rejected, thus there is a significant effect of Individual Characteristics (X) on Leadership Style (Z).

The conditions that occur in the related research object are employees who occupy shift coordinator and head positions departmentless fast and responsive in solving problems that occur in the work unit area. This means that the better the Individual Characteristics you have, the better the Leadership Style will be applied, because the Leadership Style cannot be equated with each other.

The results of this study support the results of the study (Rahmania, 2020) conducted a study entitled "Analysis of Leadership Styles Based on Individual Characteristics of Employees" with the results of the study that Individual Characteristics had a positive relationship with Leadership Style.

c. Leadership Style Affects Employee Performance

Based on the Leadership Style (Z) on Employee Performance (Y), the T statistics value is 5.599 with an -value of 0.000 . Because the value of -value is smaller than $(0.000<$ $0.05)$, then $\mathrm{H} 0$ is rejected, thus there is a significant effect of Leadership Style (Z) on Employee Performance (Y).

Conditions that occur at this time, leaders are less willing to guide employees who have difficulty when working, do not listen to employee complaints so that employees do not feel free to channel their ideas, opinions, creativity for the benefit of the company to achieve company goals which also have an impact on the relationship with joint leaders. subordinates are getting better.

Leaders apply a two-way communication system so that the relationship between leaders and subordinates is more harmonious and can create good teamwork between leaders and employees with no distance and pressure felt by workers only on departmentcertain. Leaders pay less attention to their employees by providing direction in the form of motivation and delivering criticism with poor language and not giving praise to employees with certain achievements. Based on the results of the analysis, it can be interpreted that if the leadership style is adjusted to the needs of employees, then employee performance will increase and vice versa. employees so that for 
companies that want both employee performance and company performance to be good, the right leadership style is needed.

The relationship and influence of leadership style on employee performance is also strengthened by previous research (Siswanto and Hamid, 2017) with the title The Effect of Leadership Style on Employee Performance (Study on employees of the Human Resources Management Compensation and Benefits division of PT Freeport Indonesia) with the results of the study showing that simultaneously and partially the Leadership Style variable has a significant influence on employee performance.

d. Individual Characteristics Influence Indirectly On Employee Performance Through Leadership Style

Based on the results of the T-statistics effect of 5,668 with an -value of 0.000. Because the -value is less than $(0.000<0.05)$ in other ways it is proven that $\mathrm{H} 0$ is rejected, based on these results, it is known that there is a significant effect of Characteristics Individual (X) on Employee Performance (Y) through Leadership Style (Z). The results prove that it means that Individual Characteristics affect Employee Performance Improvement even without being mediated by Leadership Style, because the TStatistic value is 5.668 with an -value of 0.000 .

And when compared with the direct effect, the value of the original sample of indirect influence of 0.411 is still below the direct influence of individual characteristics on employee performance of 0.454 , and this shows that individual characteristics can improve employee performance directly, although not through work motivation as a variable. mediation

e. Conclusion

From the results of testing and discussion, it is concluded that the existing individual characteristics need attention and improvement, because they can directly improve performance even without going through leadership style as a mediation in improving their performance. Therefore, the company should provide an example of good behavior and can be used as a model of the characteristicsindividual employee.

\section{REFERENCES}

Akbar, AN, Henson, SM and Lanna, A. (2016) 'Senescence of T lymphocytes: implications for enhancing human immunity', Trends in immunology, 37(12), pp. 866-876.

Bollen, KA and Stine, R. (1990) 'Direct and indirect effects: Classical and bootstrap estimates of variability', Sociological methodology, pp. 115-140.

Brantas, D. (2009) 'Basics of management', Bandung: Alfabeta.

Cahyono, S. (2005) 'The Influence of Organizational Culture, Leadership and Work Motivation on Human Resource Performance in the Secretariat of DPRD Central Java Province, JRBI, Vol. 1.', Indonesian Business Research Journal, 1(1), pp. 13-30.

Faiqoh, S., HS, EW and Taufiq, M. (2020) 'ANALYSIS OF THE INFLUENCE OF REWARD SYSTEMS AND INDIVIDUAL CHARACTERISTICS ON 
EMPLOYEE PERFORMANCE WITH ORGANIZATIONAL COMMITMENT AS MEDIATION VARIABLES (Empirical Study at BRID HARMAE Branch Office, 27 Brebes)', ).

Fatimah, H. et al. (2015) 'The influence of individual characteristics and organizational culture factors on employee engagement of generations $\mathrm{X}$ and $\mathrm{Y}$ ', Journal of Management Applications, 13(3), pp. 402-409.

FATIMAH, N. and DEWI, RS (2015) 'INFLUENCE OF TRANSFORMATIONAL LEADERSHIP STYLE ON ORGANIZATIONAL COMMITMENTS MEDITED BY PSYCHOLOGICAL EMPOWERMENT ON EMPLOYEES OF PT. PLN (PERSERO) IN WARU SIDOARJO', Journal of Management and Accounting Research (JUMPA), 8(1), pp. 16-25.

Fornell, C. and Larcker, DF (1981) 'Evaluating structural equation models with unobservable variables and measurement error', Journal of marketing research, 18(1), pp. 39-50.

Gaffar, ID (2017) 'The Influence of Individual Characteristics on Employee Performance at PT Sumber Alfaria Trijaya in Makassar', Economics Bosowa, 3(5), pp. 13-25.

Hamzah, YWP and Suwoko, S. (2020) 'The Influence of Autocratic Leadership Style on Employee Work Productivity at PT. Indonesian Mineral Quality Services in Samarinda' City, Borneo Student Research (BSR), 1(2), pp. 949-955.

Hutapea, P. and Nurianna Thoha, MBA (2008) Competence plus. Main Library Gramedia.

Iqbal, M. (2015) 'Panel Data Regression (2): Analysis Phase', Retrived From https://dosen. bandage. en/data-regression-panel-2-stage-analysis.

Islami, KB and Kusumaningsih, LPS (2020) 'Relationship between Perception of Autocratic Leadership Style and Employee Performance of PT. Bank BPR Nusamba Ampel Boyolali', Psisula: Periodic Proceedings of Psychology, 2, pp. 94-104.

Ivancevich, JM (2007) 'Human resource management', New York: McGrawHill.

Kridharta, D. and Rusdianti, E. (2017) 'Analysis of the influence of individual characteristics, organizational commitment, and job satisfaction on employee performance with motivation as an intervening variable', Journal of Economics and Business Research, 10(3), pp. 232-247.

Latan, H. and Ghozali, I. (2016) 'Partial Least Square Concepts, Methods and Applications Using WarpPLS 5.0', Semarang: Diponegoro University Publishing Agency.

Lestary, L. and Harmon, H. (2018) 'The Effect of the Work Environment on Employee Performance', Journal of Business and Investment Research, 3(2), p. 94. doi:10.35697/jrbi.v3i2.937.

Mangkunegara, AP and Agustine, R. (2016) 'Effect of Training, Motivation and Work Environment on Physicians' Performance', Academic Journal of Interdisciplinary Studies, 5(1), p. 173. 
Marcoulides, GA, Chin, WW and Saunders, C. (2009) 'A critical look at partial least squares modeling', MIS Quarterly: Management Information Systems, 33(1), pp. 171-176. doi: 10.2307/20650283.

Mayer, JD (2004) 'Is Emotional Intelligence Old Wine in New Bottles? A Conversation Between Frank Landy and John D. Mayer. Retrieved November 20 September, 2005'.

Novi, AR (2013) 'Operational Budget Analysis as a Performance Measurement Tool for PDAM Kabupaten Ponorogo', Journal of Chemical Information and Modeling, 53(9), pp. 1689-1699. Available at: http://prosiding.unipma.ac.id/index.php/FIPA/article/view/204.

Pohan, RA, Hayati, RH and Sahputra, DS (2018) 'The Contribution of Achievement Motivation and Self-Concept to Responding Activities in Learning and Its Implications in Guidance and Counseling', Wahana Didaktika: Journal of Educational Science, 16(2), pp. 145-161.

Pramundi, D. and , Mochamad Mochklas, DS (2021) 'EMPLOYEE PERFORMANCE OF COAL BRICKET COMPANIES':, 17.

Primadani, C. and Sumiati, S. (2019) 'The Influence of Individual Characteristics of Employee Development and Employee Commitment to Job Satisfaction and Employee Performance at PT. Saraya Anugrah ...', Management \& Accounting Research ..., 03(02). Available at: https://jurnal.ikbis.ac.id/global/article/view/243.

Rahmania, U. (2020) 'Analysis of leadership styles based on individual characteristics of employees at PT Asuransi Jasa Indonesia Malang Branch Office', UM Student Thesis.

Sedarmayanti, H. (2012) 'Good governance', second revised edition, Bandung: Mandar Maju.

Siswanto, RD and Hamid, D. (2017) 'The Influence of Leadership Style on Employee Performance (Study on employees of PT Freeport Indonesia's Human Resources Management Compensation and Benefits division)', Journal of Business Administration, 42(1), pp. 189-198.

Soelistya, D. (2014) 'The Influence of Participatory Leadership Style and Communication on Work Motivation and Its Impact on Employee Work Performance', Journal of Economics and Management, 1(1), pp. 1-10.

Soepomo, P. (2013) 'Using the Competency Gap Method (Case Study of Perkasa Jaya Compuretail Company)', pp. 574-583.

Sugiyono, D. (2013) 'Educational research methods with quantitative, qualitative and R\&D approaches'.

Suhepi, A. and Syah, TYR (2018) 'The Influence of Training Design, Individual Characteristics, and Work Environment on Training Transfer and Its Impact on Employee's Performance', International Journal of Economics, Commerce and Management, 4(3).

Suryani, NK, Sugianingrat, IAPW and Laksemini, KDIS (2020) Human Resource Performance: Theory, Application and Research. Nilachakra. 
Sutedjo, AS and Mangkunegara, AP (2013) 'The Influence of Competence and Work Motivation on Employee Performance at PT. Inti Kebun Sejahtera', BISMA (Business and Management), 5(2), pp. 120-129.

Tampi, BJ (2014) 'The Influence of Leadership Style and Motivation on Employee Performance at PT. Bank Negara Indonesia, tbk (regional sales manado)', Acta Diurna Communications, 3(4).

Trang, DS (2013) 'Leadership style and organizational culture influence on employee performance', EMBA Journal: Journal of Economic Research, Management, Business and Accounting, 1(3).

WAHJONO, SI (2018) 'The Situational Leadership Model in Family Companies (Case of SMEs in Wedoro Sidoarjo Industrial Center)', BISMA (Business and Management), 3(1), p. 1. doi:10.26740/bisma.v3n1.p1-14.

Wirawan, A. and Afani, IN (2018) 'The Influence of Reward and Punishment on Employee Performance and Motivation at CV Media Kreasi Bangsa', Journal of Applied Business Administration, 2(2), pp. 242-257. 